\title{
Performance Dissimilarities in the Activity of Foreign and Romanian- Owned Companies: What Lessons to be Learned?
}

\author{
Alexandra HOROBET \\ The Bucharest University of Economic Studies, Romania \\ alexandra.horobet@rei.ase.ro \\ Oana POPOVICI \\ The Bucharest University of Economic Studies, Romania \\ popovici.oana@yahoo.com
}

\begin{abstract}
Our paper addresses the activity of the foreign-capital controlled companies versus domestic companies in Romania, in order to highlight the differences in performance between the two categories of firms, given the increased importance of foreign-owned companies in the Romanian economy in recent years. The research and analysis are based on data available from Eurostat FATS - Foreign Affiliates Statistics. The comparative analysis of performance between foreign-owned and Romanian-owned companies is carried out for the period 2008-2014 on two levels: (i) The total performance of foreign-owned and Romanianowned companies; (ii) The determination of the "average"-sized foreign-owned and Romanian-owned company attributes. Our main findings show that foreign-owned companies generate higher cash flows that are essential for business development, backed up by a higher value of production, higher turnover and higher gross operating profits, despite a higher number of employees and higher personnel costs compared to Romanian-owned companies. At the same time, Romanian-owned companies claim higher profitability ratios due to their reduced dimensions.
\end{abstract}

Keywords: performance; foreign-owned companies; Romanian-owned companies; foreign direct investment;

JEL Codes: F23; L25; O10;

\section{Introduction}

The prerequisites of a country's economic development lie nowadays in the abundance of capital. Public investment sources are often limited by different national interests that tend to be prioritized: the control of the budget deficit, redistributions favouring the social duties etc. While in the absence of investments, the economy loses, one thing is clear: if public resources are limited, then private funding should be encouraged.

In this context, foreign direct investments (FDI) are considered a healthy source for the economic growth of a country, as the literature generally acknowledges, and an opportunity for recovery in times when economic stability is at stake. For Romania in particular, FDI's contribution to economic growth and development was substantial in the past few years, due to its impact on technological development, export growth and knowhow imports. Still, Romania's opening for FDI hardly started in 2000, once with large privatizations; after this moment, foreign investors were encouraged by the upward trend of the Romanian economy and the favourable external environment, outlined by the EU accession forecasts and the beginning of a global expansion period. While the 2003-2008 period marks an expansion of FDI, with flows that increased more than five times, 
Romania began to lose its attractiveness for foreign investors after 2009, due to the effects of the global financial crisis and the European sovereign debt crises, accompanied in the following years by local instability in the economic and political areas. Therefore, as compared to the neighbouring countries that are also members of the European Union, Romania recorded weak performances in attracting FDI, although it has several locational advantages for foreign investors, such as a strategic geographical position, a large market and low labour costs.

The interest of the present study is to assess the achievements of FDI in the Romanian economy by comparing the performance of foreign-owned companies with the domestic ones. Romania tapped the interest of foreign investors, who have made greenfield investments and provided new jobs, supported consumption and expanded production capacity, including in times of crisis. The present approach aims at providing a clearer picture of the effects generated by the activity of foreign capital companies that are present in Romania and can be a starting point for substantiating public policy measures in this field. The objective of this study is to highlight the results of the activity of companies with foreign capital compared to the ones with Romanian capital, first of all as a global performance, and secondly through an innovative analysis that compares the characteristics of the "average firm" with foreign versus Romanian capital. The present analysis is a novel one for the Romanian economy, as there are very few studies referring to such comparisons even at European or international level, at least to our knowledge. The paper is organised as follows: Section 2 outlines the theoretical and empirical framework that supports our study, Section 3 presents the data and methodology, Section 4 discusses the main results and Section 5 concludes.

\section{Literature Review}

When assessing the performance of companies, the discussion should encompass, on one side, the drivers of performance, and on the other side, the effective performance and how this performance translates into economic wealth for the hosting country. We will briefly relate to these dimensions hereinafter especially related to the FDI presence.

The concept of industrial organization was the main strand under which the drivers of the performance of companies were theoretically framed, due to the work of Bain and Mason (Porter, 1981). At that point, the company's competitiveness was assessed in the national/domestic context, depending on the industry's environment in which the firm activates, the strategy adopted and the results obtained, also known as the "structureconduct-performance" model. Once with globalization, literature started to emphasize more the own capabilities of companies for creating competitive advantages. Hawawini et al. (2003) refers to a clear set of "specific capabilities" which largely contribute to shaping the performance of the company, while Dunning (1973, 1988) specifically addresses the "ownership advantages" of the companies in their decision to internationalize. Horobe et al. (2018) refer to a comprehensive approach towards assessing firm performance that should include industry, location and external factors in explaining the competitiveness of the companies. While the industry-related factors encompass the particularities of being part of both a particular industry and a corporate family, the location factors more generally delineate the environment of the host country, while the external ones are related to the importance granted by integration of the country in the international flows, through openness for international trade and flows. 
In addition, the literature points to differences between foreign and domestic-owned companies due to the fact that companies that internationalized their business have managed to surpass obstacles such as the liability of foreignness or transaction costs and usually benefit from being part of an international network of affiliates (see, for example, Weche Gelubcke, 2011). In this regard, the conclusion of Sgard (2001) points to a higher performance of companies with foreign ownership as compared to the domestic firms. The work of Konings (2001) indicates that foreign involvement at firm-level tends to lead to a better performance for the companies in Bulgaria, Poland and Romania than for the domestic ones. In addition, specific sectors seem to require a deeper comprehension related to the ownership of the companies; for example, studies indicate that the performance of the services companies is increasingly explained by the foreign ownership (Kafouros et al., 2008; Buckley et al., 2002).

The literature is divided as regards the FDI effects on the economic and social welfare of a country. Acarvaci and Ozturk (2012) conducted one of the studies highlighting the positive impact of FDI on the economic development; for transition countries in Central and Eastern Europe, FDI demonstrated an important role for enhancing modernization (Hanousek et al., 2011). Belaşcu et al. (2017) also proved a positive impact on the economic growth for five countries in this region. FDI also contribute to stimulating exports, as confirmed by the works of Beugelsdijk et al. (2008), Damijan et al. (2008), Kutan and Vuksic (2007). While the positive effects translate into increased productivity and economic growth, there are views that argue that foreign presence could lead to a dependence of the economy on foreign capital; therefore, the policies of these companies could be harmful for local firms, insufficiently prepared for competing with multinationals. For example, Moura and Forte (2010) conducted an analysis where the results of the studies attesting both positive and negative impact of FDI are presented and the sources of these differences are explained. In recent decades, the overall political opinion changed towards favouring FDI, which are seen rather as sources for generating competitiveness and economic growth for host countries.

However, the effects of foreign investment in an economy depend on many factors. On one side, there are the nature and the characteristics of the sector where multinational firms are present, the time period in which the impact of foreign investment is analysed, the mode of entry on the host market, the strategies of the multinational companies etc. On the other side, a very important role is attributed to the strategies of the host country's governments towards foreign investments and their efforts in attracting and orienting foreign investment. For example, Bartels and Crombrugghe (2009) warn on the need of calibrating investment policy instruments in the new context required by globalization.

Generally, literature points that the impact of FDI in the host economies could be either direct or indirect. The direct effect is determined by the investments made by multinational companies in companies created or taken over in host economies. The indirect effect represents the spillover generated by the initial investment to which other companies than the direct investment firm are exposed, who are not the beneficiaries of a capital and technology transfer directly from multinational firms. There are significant studies in the literature that address this topic, among which the meta-analyses of Irsova and Havranek (2013), Gorg and Strobl (2001), Meyer and Sinani (2009), Hanousek et al. (2011). The brief scheme presented in Figure 1 traces the main spillovers generated by FDI and identified in the literature. 
Figure 1. FDI impact on host economies

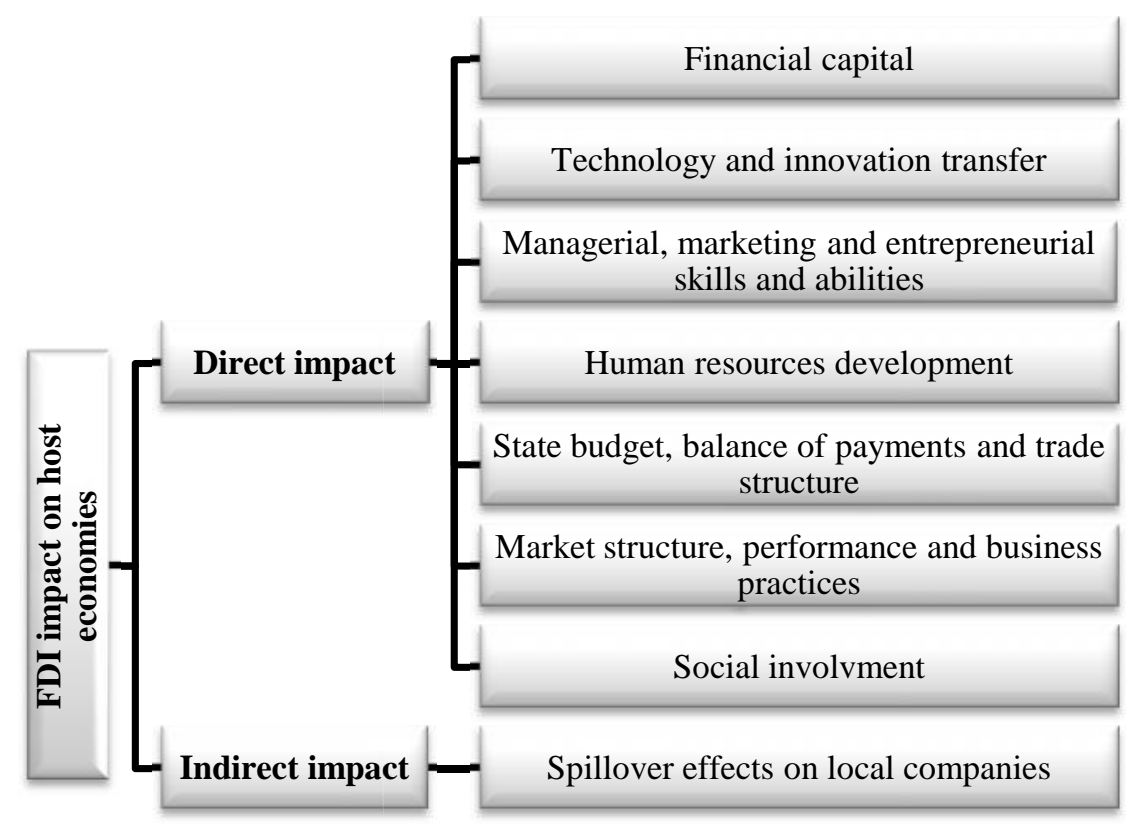

Source: Authors

The direct impact of FDI is reflected at microeconomic level, starting with the financial capital provided by the multinational firm (either through direct equity, reinvested profits or loans to the local firm/companies) and continuing with the transfer of technology and innovation, which also enhances or is enhanced by research and development expenditures. Local firms are exposed to a whole range of skills and abilities in the field of management, marketing or entrepreneurship that were initially missing or insufficiently developed. The quality of human resources is upgraded, not only through raising salaries or incomes, but also by providing training programs, that will further lead to the emergence of new jobs and skills.

At this level, the effects of FDI can be seen in the increasing performance and competitiveness of local firms that are supported by the multinational companies and in the business practices they promote. From this microeconomic level, the effects of the FDI could be propagated at the sectoral level by altering the structure of the markets and the degree of concentration in favour of both end-users and suppliers.

Finally, at macroeconomic level, the effects of FDI can be assessed through higher contributions to the state budget, the impact on the balance of payments and also by altering the structure of exports and improving the trade balance.

The indirect impact of FDI on host economies appears in the form of training and learning spillovers on local firms, mainly as a result of mimetic behaviour of these ones. These effects include technology transfer, human resource development, or increased performance of local businesses competing with multinational companies' subsidiaries. 


\section{Data and Methodology}

The paper assesses the activity of companies with foreign capital versus those with domestic capital in order to highlight the differences in performance between the two categories of firms. The analysis is based on data available from FATS - Foreign Affiliates Statistics, published by Eurostat. The FATS encompass the FDI companies in whose case the share of foreign capital is at least $50 \%$ of the subsidiary's capital. Due to the fact that such companies form the largest part of FDI companies in Romania, by accounting for $83.7 \%$ of the total turnover of FDI enterprises and employing $87 \%$ of employees in 2014, we consider that the comparison between the performance of FATS and Romanian companies is appropriate. The data used have an annual frequency and cover the period 2008-2014, the last year for which comparable data are available.

The analysis of performance differences between foreign-owned companies and Romanian-owned companies is carried out on two levels, as follows: (i) The overall performance of foreign-owned and Romanian-owned companies; (ii) The determination of the "average"-sized foreign-owned and Romanian-owned companies' attributes. The indicators for describing performance are presented in Table 1.

Table 1. Indicators used for describing companies' performance

\begin{tabular}{|c|c|c|}
\hline & Indicator & Definition and measurement unit \\
\hline \multirow[t]{5}{*}{$\begin{array}{l}\text { Overall } \\
\text { performance }\end{array}$} & Value added at factor cost & $\begin{array}{l}\text { Gross income from operating activities after adjusting } \\
\text { with operating subsidies and indirect taxes. Million euro }\end{array}$ \\
\hline & $\begin{array}{l}\text { Gross investment in } \\
\text { tangible goods - total and } \\
\text { per employee }\end{array}$ & $\begin{array}{l}\text { Investment all tangible goods. Includes the new and } \\
\text { existing tangible capital goods, whether bought from third } \\
\text { parties or produced for own use (i.e. capitalised } \\
\text { production of tangible capital goods), having a useful life } \\
\text { of more than one year including non-produced tangible } \\
\text { goods such as land. Investments in intangible and } \\
\text { financial assets are excluded. Million euro }\end{array}$ \\
\hline & $\begin{array}{l}\text { Personnel costs - total and } \\
\text { per employee }\end{array}$ & $\begin{array}{l}\text { The total remuneration, in cash or in kind, provided by the } \\
\text { employer to all employees. Million euro. }\end{array}$ \\
\hline & $\begin{array}{l}\text { Labour productivity: } \\
\text { 1. Apparent labour } \\
\text { productivity } \\
\text { 2. Wage adjusted labour } \\
\text { productivity }\end{array}$ & $\begin{array}{l}\text { 1. Gross value added per person employed. Thousand } \\
\text { euro } \\
\text { 2. Apparent labour productivity by average personnel } \\
\text { costs. Percentage }\end{array}$ \\
\hline & $\begin{array}{l}\text { Gross operating surplus - } \\
\text { total and per employee }\end{array}$ & $\begin{array}{l}\text { The additional amount generated by the company's } \\
\text { activities after paying for labour costs. It represents the } \\
\text { capital available to the company for the payment of } \\
\text { creditors, taxes, and possibly investment financing, either } \\
\text { totally or partially. Million euro }\end{array}$ \\
\hline \multirow{8}{*}{$\begin{array}{l}\text { The } \\
\text { performance of } \\
\text { the "average" } \\
\text { company }\end{array}$} & \multicolumn{2}{|c|}{ Value added at factor cost per enterprise. Million euro } \\
\hline & \multicolumn{2}{|c|}{ Turnover per enterprise. Million euro } \\
\hline & \multicolumn{2}{|c|}{ Number of employees per enterprise } \\
\hline & \multicolumn{2}{|c|}{ Personnel costs per enterprise. Million euro } \\
\hline & \multicolumn{2}{|c|}{ Value of production per enterprise. Million euro } \\
\hline & \multicolumn{2}{|c|}{ Gross investment in tangible goods. Million euro } \\
\hline & \multicolumn{2}{|c|}{ Gross operating surplus per enterprise. Million euro } \\
\hline & \multicolumn{2}{|c|}{ Gross operating rate (gross operating surplus to turnover). Percentage } \\
\hline
\end{tabular}

Source: Authors. Definitions of indicators from Eurostat 


\section{Results and Discussion}

\subsection{Assessment of overall performance of foreign versus domestic-owned companies}

Table 2 summarizes the values of performance indicators mentioned above for the years 2008 and 2014, as well as the Compound Annual Growth Rate (CAGR) for the period 2008-2014. The table also indicates the ratio between the value of these indicators for the companies with foreign capital compared to the ones with Romanian capital in 2008 and 2014 , in order to highlight the overall growth of the importance of foreign-owned companies in the analysed period.

(1) Value added at factor cost. On overall economy, the value added at factor cost had a general decreasing trend, with yearly fluctuations, especially for companies with domestic capital (Figure 2). Thus, if the domestic-owned companies realised an added value of EUR 35,696 million compared to only EUR 23,148 million for foreign-owned companies in 2008, at the end of 2014 the added value created by the Romanian companies was EUR 31,338 million (lower than in 2008), while the one created by foreign-owned companies reached EUR 24,522 million, slightly increasing as compared to 2008. Under the conditions of different CAGR for the two categories of companies - a positive rate of $0.83 \%$ for foreign-owned enterprises and a negative one (-1.84\%) for the Romanian companies - the ratio between the two types of companies in terms of value added has increased in favour of those with foreign capital, from $65 \%$ in 2008 to $78 \%$ in 2014.

Figure 2. Evolution of value added at factor costs

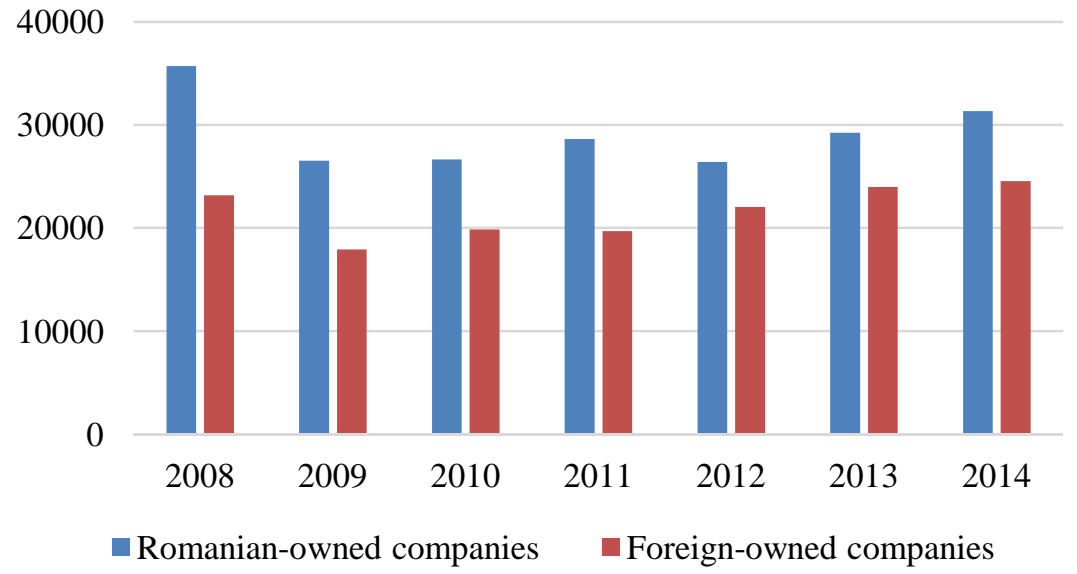

Source: Developed by authors based on Eurostat-FATS data

(2) Gross investment in tangible goods - total and per employee. The evolution of this indicator between 2008 and 2014 highlights the superior resilience of the companies with foreign capital compared to the ones with Romanian capital, due to the lower investment volatility manifested in the first case (Figure 3). Except for the years 2008 and 2011, when the investments made by the companies with Romanian capital have definitely dominated those made by the companies with foreign capital (1.93 times higher in 2008 and 2.16 times higher in 2011), the investments of foreign-owned firms are relatively similar with those of Romanian companies in the rest of the period. 
Table 2. Performance indicators of companies with foreign and domestic capital

\begin{tabular}{|c|c|c|c|}
\hline & \multicolumn{3}{|c|}{ Overall economy } \\
\hline & 2008 & 2014 & CAGR \\
\hline \multicolumn{4}{|l|}{ Value added at factor cost (mil. Euro) } \\
\hline Foreign-owned companies & 23147.50 & 24522.30 & $0.83 \%$ \\
\hline Romanian-owned companies & 35696.20 & 31337.50 & $-1.84 \%$ \\
\hline Foreign versus Romanian-owned companies ${ }^{1}$ & 0.65 & 0.78 & - \\
\hline \multicolumn{4}{|l|}{ Gross investment in tangible goods (mil. Euro) } \\
\hline Foreign-owned companies & 13154.90 & 11410.60 & $-2.01 \%$ \\
\hline Romanian-owned companies & 25461.00 & 12043.40 & $-10.14 \%$ \\
\hline Foreign versus Romanian-owned companies & 0.52 & 0.95 & - \\
\hline \multicolumn{4}{|l|}{ Investment per person employed (Euro) } \\
\hline Foreign-owned companies & 13.40 & 11.10 & $-2.65 \%$ \\
\hline Romanian-owned companies & 7.40 & 4.30 & $-7.46 \%$ \\
\hline Foreign versus Romanian-owned companies & 1.81 & 2.58 & - \\
\hline \multicolumn{4}{|l|}{ Personnel costs (mil. Euro) } \\
\hline Foreign-owned companies & 9539.30 & 11198.40 & $2.32 \%$ \\
\hline Romanian-owned companies & 16412.00 & 14776.00 & $-1.49 \%$ \\
\hline Foreign versus Romanian-owned companies & 0.58 & 0.76 & - \\
\hline \multicolumn{4}{|l|}{ Personnel costs per employee (thousand Euro) } \\
\hline Foreign-owned companies & 9.90 & 11.00 & $1.52 \%$ \\
\hline Romanian-owned companies & 4.90 & 5.50 & $1.66 \%$ \\
\hline Foreign versus Romanian-owned companies & 2.02 & 2.00 & - \\
\hline \multicolumn{4}{|l|}{ Apparent labour productivity (thousand Euro) } \\
\hline Foreign-owned companies & 23.60 & 23.80 & $0.12 \%$ \\
\hline Romanian-owned companies & 10.40 & 11.20 & $1.06 \%$ \\
\hline Foreign versus Romanian-owned companies & 2.27 & 2.13 & - \\
\hline \multicolumn{4}{|l|}{ Wage-adjusted labour productivity $(\%)$} \\
\hline Foreign-owned companies & 242.70 & 219.00 & $-1.46 \%$ \\
\hline Romanian-owned companies & 217.50 & 212.10 & $-0.36 \%$ \\
\hline Foreign versus Romanian-owned companies & 1.12 & 1.03 & - \\
\hline \multicolumn{4}{|l|}{ Gross operational profit (mil. Euro) } \\
\hline Foreign-owned companies & 13608.20 & 13323.80 & $-0.30 \%$ \\
\hline Romanian-owned companies & 19284.20 & 16561.50 & $-2.15 \%$ \\
\hline Foreign versus Romanian-owned companies & 0.71 & 0.80 & - \\
\hline \multicolumn{4}{|c|}{ Gross operational profit per person employed (thousand Euro) } \\
\hline Foreign-owned companies & 13.90 & 12.90 & $-1.06 \%$ \\
\hline Romanian-owned companies & 5.60 & 5.90 & $0.75 \%$ \\
\hline Foreign versus Romanian-owned companies & 2.48 & 2.19 & - \\
\hline
\end{tabular}

Source: Eurostat - FATS and authors' computations

\footnotetext{
${ }^{1}$ Shows the ratio between the indicator's values for foreign-owned and for Romanian-owned companies.
} 
Figure 3. Evolution of gross investments in tangible goods and of personnel costs
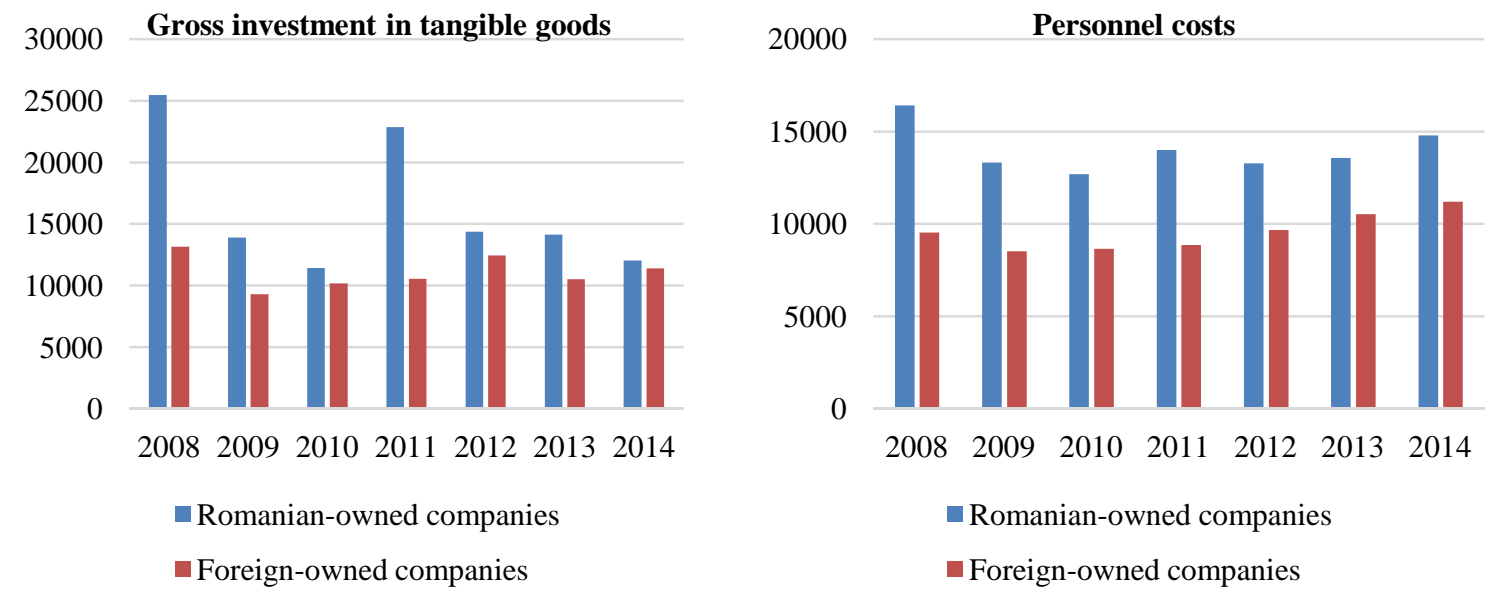

Source: Developed by authors based on Eurostat-FATS data

Overall, gross investment by foreign-owned firms declined at an average annual rate of only $2.01 \%$ (from EUR 13,154.90 million in 2008 to EUR 11,410.60 million in 2014), while those realized by companies with Romanian capital dropped at a fivefold annual rate of 10.14\% (from EUR 25,461 million in 2008 to EUR 12,043.40 million in 2014). Such an evolution led to a doubling of the ratio between the gross investments of the two types of firms in favour of the foreign-owned firms, from $51.7 \%$ in 2008 to $94.7 \%$ in 2014. Still, besides the quantitative component of the investments, given by their nominal value, a comprehensive assessment also relates to their quality, namely the efficiency and the ability to generate cash and growth flows for companies and the economy. Or, from this point of view, foreign-owned firms perform well above those with domestic capital during the analysed period, suggesting that their investments generated higher positive net present values compared to those achieved by Romanian companies, as shall be noticed below.

The investments per employee is an indicator measuring the adjustment of gross investments in tangible assets of companies to the number of employees, allowing a better understanding of the investment activity of companies according to their size, measured by the number of employees. Data shows that investments per employee were higher in foreign-owned companies compared to those with Romanian capital. In 2008, the investment per person employed was EUR 13.40 for the companies with foreign capital and EUR 7.40 for the companies with Romanian capital. In 2014, the investments per employee were lower than in 2008 for both foreign and Romanian capital companies (EUR 11.10 and EUR 4.30 respectively), as a result of the difficult times after the Global financial crisis of 2007-2009 and the necessary business adjustments required by those turbulent times. These evolutions are explained by the lower decline of the investments made by the companies with foreign capital during the period 2008-2014 compared to the investments of the domestic-owned companies, as the number of persons employed by the foreign capital companies increased, but decreased for the Romanian capital companies, respectively.

(3) Personnel costs - total and per employee. Given the higher number of persons employed by the Romanian-owned companies compared to those with foreign capital, the fact that the personnel expenses for the Romanian companies were higher during the whole period 2008-2014 is not a surprise (Figure 3). At the same time, however, there are some peculiarities and developments worth mentioning. 
First, foreign companies increased their personnel expenses between 2008 and 2014 at an average annual rate of 2.32\%, from EUR 9,539.3 million to EUR 11,198.4 million, while the Romanian firms reduced staff spending at an average annual rate of $1.49 \%$, from EUR 16,412.0 million to EUR 14,776.0 million. As a consequence, the ratio of this indicator for the two categories of companies has improved in favour of foreign firms from $58 \%$ in 2008 to $76 \%$ in 2014 , which means that these enterprises increased their contribution to the overall population income and government budget through the various wage-related taxes during this period, while the contribution of Romanian companies has diminished.

Second, if the analysis is carried out at the level of employees, the costs were increasing for companies with foreign capital from EUR 9.90 to EUR 11.0 (an average annual rate of $1.52 \%$ ) and from EUR 4.90 to EUR 5.50 (an annual average rate of 1.66\%) for companies with Romanian capital. We mention that, in this period, the number of persons employed by foreign-owned companies increased, while it decreased for companies with Romanian capital.

(4) Labour productivity. Eurostat statistics provide two indicators for measuring the labour productivity, as follows: (1) A measure of gross productivity or gross value added per person employed - labelled "Apparent labour productivity"; and (2) A measure of labour productivity adjusted for wages, calculated as the ratio between the value added and the personnel costs - labelled "Wage-adjusted labour productivity".

Irrespective of the year considered and the indicator used, labour productivity was always higher for the companies with foreign capital to the detriment of the domestic-owned companies (see Figure 4), but the differences between the two categories of firms were more pronounced in the case of the apparent productivity compared to the adjusted wage productivity. These differences are explained by the higher number of persons employed by the Romanian companies, on one side, and by the lower gross value added generated in the economy by the companies with foreign capital, on the other side. At the same time, apparent labour productivity grew slightly for companies with foreign capital in 2008 (when it was EUR 23.60) by 2014 (EUR 23.80), but the increase was accompanied by fluctuations - for example, in 2009, its value was only EUR 19).

Figure 4. Evolution of labour productivity
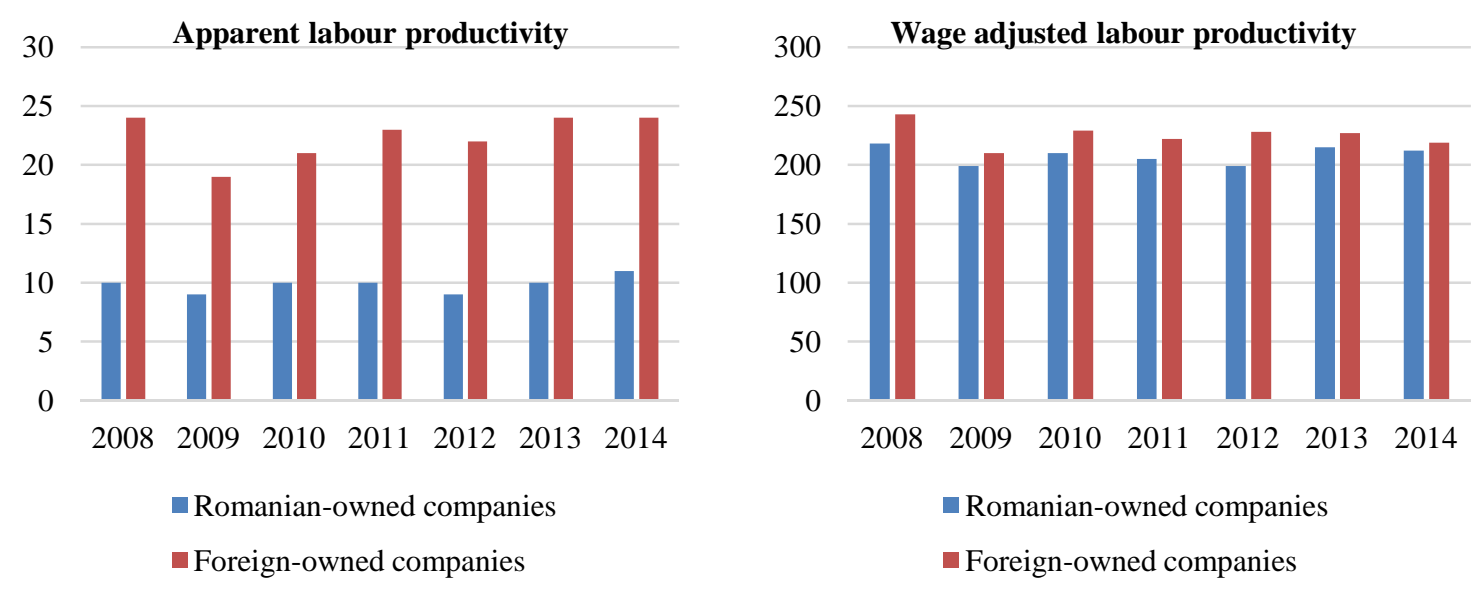

Source: Developed by authors based on Eurostat-FATS data 
For the companies with Romanian capital, the increase in apparent productivity was slightly higher, recording an average annual rate of $1.06 \%$ (compared to $0.12 \%$ for the foreign-owned firms), but it reached only EUR 11.20 in 2014. On the other hand, the productivity adjusted for personnel costs had different evolutions as compared to the apparent productivity, decreasing between 2008 and 2014 for companies with foreign capital - from EUR 242.70 to EUR 219 - and for those with Romanian capital - from EUR 217.50 to EUR 212.10. The explanation is given by the higher increase in the case of the personnel costs as compared to the gross added value for the companies with foreign capital in the period 2008-2014 and, in the case of the domestic-owned companies, the more significant decrease of the value added compared to the personnel costs in the same period.

(5) Gross operating surplus - total and per employee. The differences in performance between companies with foreign capital and those with domestic capital are ultimately reflected in the gross operating surplus, which represents the amount available to the company for the payment of creditors and taxes and which allows the financing of possible investments. As can be seen in Figure 5, foreign-owned companies have globally generated lower operating profits compared to domestic-owned firms in the period 20082014. After adjusting the indicator to the number of employees, the performance of foreign-owned companies stands well above those of Romanian companies, with the gross operating profit per employee being approximately 2-3 times higher than that recorded by Romanian companies.

The gross operating profit per employee generated by the companies with foreign capital was of EUR 13.90 thousand in 2008, compared to a value of EUR 5.60 thousand showed by the companies with Romanian capital. At the same time, the operational profit per employee decreased for the foreign capital companies to EUR 12.90 thousand until 2014 (at an average annual rate of $1.06 \%$ ), and increased for the companies with Romanian capital at EUR 5.90 thousand (at an average annual rate of $0.75 \%$ ).

Figure 5. Evolution of gross operating surplus
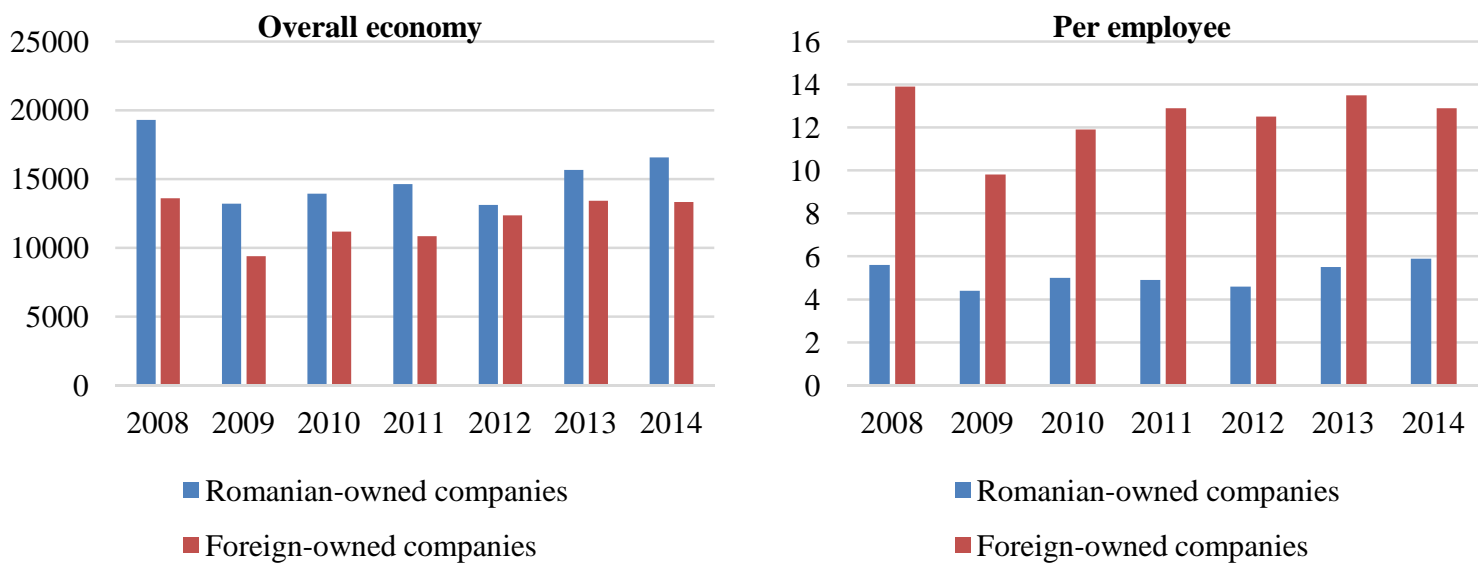

Source: Developed by authors based on Eurostat-FATS data

\subsection{The performance attributes of the "average firm" with foreign and domestic capital}

The overall performance, generally in favour of foreign-owned companies, has a correspondent in the attributes of the "average firm" and their evolution over the period 2008-2014. Table 3 presents the characteristics of the "average firm" (related to the value 
added at factor costs, turnover, persons employed, personnel costs, investments, production value, operational profit and gross operational profit margin) and their values for 2014 and 2008 for both foreign and Romanian companies. As it is easily observed, the foreign capital "average firms" have quite different characteristics compared to Romanian-owned companies and, overall, the former performed better than the later on almost all indicators.

Table 3. Characteristics of companies with foreign and domestic capital

\begin{tabular}{|l|c|c|c|c|}
\hline \multirow{2}{*}{} & \multicolumn{2}{|c|}{ Foreign-owned companies } & \multicolumn{2}{c|}{ Romanian-owned companies } \\
\cline { 2 - 5 } & $\mathbf{2 0 0 8}$ & $\mathbf{2 0 1 4}$ & $\mathbf{2 0 0 8}$ & $\mathbf{2 0 1 4}$ \\
\hline Valued added at factor cost (mil. Euro) & 2.031 & 0.832 & 0.072 & 0.074 \\
\hline Turnover (mil. Euro) & 9.684 & 4.015 & 0.297 & 0.300 \\
\hline Number of persons employed & 86 & 35 & 7 & 7 \\
\hline Personnel costs (mil. Euro) & 0.837 & 0.380 & 0.033 & 0.035 \\
\hline Investments in tangible goods (mil. Euro) & 1.154 & 0.387 & 0.051 & 0.028 \\
\hline Production value (mil. Euro) & 2.092 & 2.763 & 0.300 & 0.213 \\
\hline Operational profit (mil. Euro) & 1.194 & 0.452 & 0.039 & 0.039 \\
\hline Gross operational profit margin (\%) & $12.33 \%$ & $11.25 \%$ & $13.11 \%$ & $12.96 \%$ \\
\hline
\end{tabular}

Source: Eurostat - FATS and authors' computations

The value added at factor costs of the "average firm" was EUR 2.031 million in 2008 and EUR 0.832 million in 2014 for foreign-owned firms, but only EUR 0.072 million in 2008 and EUR 0.074 million in 2014 for Romanian capital companies. The ratio between the value added of the foreign-owned and Romanian-owned "average firm" was 28.17 in 2008 and 11.31 in 2014, the decrease of this ratio being determined by the reduction of the value added by the "average firm" with foreign capital.

The turnover of the foreign-owned "average firm" was EUR 9.586 million in 2008 and EUR 4.015 million in 2014, while for the domestic average-sized company it reached EUR 0.297 million in 2008 and EUR 0.3 million in 2014, which is equivalent to an average turnover of the foreign-owned firm more than 32 times higher than that of a Romanian company in 2008 and more than 13 times higher in 2014. It should be noted that the reduction of this ratio is due to a larger reduction in the figure of average-sized firm with foreign capital than the increase in the average turnover of Romanian-owned company.

The foreign-owned "average firm" employs more persons than the Romanian one, the average number of employees reaching 86 in 2008 in the first type of companies as compared with only 7 in the domestic ones in 2008, and of 35 employees, respectively 7 in 2014. Consequently, the higher number of employees for foreign-owned firms results in higher personnel costs. The foreign-owned "average firm" borne personnel costs more than 25 times higher than those of the Romanian-owned companies in 2008, the ratio falling to almost 11 in 2014 in the whole economy.

The situation also inclines in the favour of the "average" foreign-owned company as regards the investments in tangible goods. The higher value of investments made by the "average-sized" firm with foreign capital is the natural result of a higher production value, a higher turnover and a higher operating profit compared to the "average firm" with Romanian capital: generating higher cash flows, the "average firm" with foreign capital is capable of making higher investments than the one with Romanian capital. The 
ratio of the values of investments in tangible assets between the companies with foreign and Romanian capital was 22.44 in 2008 and 13.70 in 2014.

The production value also shows the same substantial differences between the "average firm" with foreign and domestic capital respectively, both in 2008 and in 2014. Overall economy, the value of the production realized by the "average firm" in 2008 reached EUR 2.09 million, more than 7 times the performance of the average Romanian firm (EUR 0.213 million) and EUR 2.763 million in 2014, more than 13 times higher than the one realized by the "average firm" with Romanian capital (EUR 0.213 million).

The gross operating profit depicts the same differences between the two categories of companies: the "average firm" with foreign capital had an operating profit of EUR 1.19 million in 2008 compared to EUR 0.039 million for the "average firm" with Romanian capital (a ratio of 30.65) and of 0.452 million Euro in 2014, compared to 0.039 million Euro of the average Romanian-owned firm (the ratio falls to 11.63, the drop being related to the decrease of the operating profit for the "average firm" with foreign capital, as the domestic-owned average firm maintains its operating profit level).

Finally, the gross operating profit margin shows higher values for Romanian-owned companies, a situation which is normal; generally smaller firms register higher profitability rates as compared to the larger ones. Therefore, in 2008 the "average firm" with foreign capital had a profit rate of $12.33 \%$, while the one with domestic capital rose to $13.11 \%$ in 2008 , while in 2014 the "average firm" with foreign capital had a profit rate of $11.25 \%$, and the Romanian one $-12.96 \%$.

Concluding, the "average firm" with foreign capital is larger, due to the higher number of employees, and has higher personnel costs than the "average firm" with Romanian capital, but it manages to obtain a higher value of production, a higher turnover and a higher gross operating profit, which allows for higher investments and higher gross value added compared to the "average firm" with Romanian capital. In our opinion, the higher profitability rate for companies with Romanian capital conceals a significantly lower capacity to generate substantial investments and important added value. Instead, foreignowned firms have managed to obtain higher profitability - measured by significantly high cash flows - than Romanian ones.

\section{Conclusions}

The 2008-2014 period was not an easy one either for foreign capital companies or for those with Romanian capital. Faced with the effects of the economic and financial crisis and the recession that affected the European Union, they saw themselves in a situation where the very good performances recorded in 2007-2008 decreased substantially, as shown by the main business indicators. In this framework, the main findings of our research are the following: (i) the performance decrease was mainly recorded during the period 2009-2012; starting with 2013, the general trend is to return to pre-2009 values; (ii) the companies with Romanian capital have been negatively affected to a greater extent than companies with foreign capital; the latter recorded a faster recovery, so that by the end of 2014 their performance was higher than in 2008; (iii) the "average firm" with foreign capital has a higher number of employees and higher personnel costs than the "average firm" with Romanian capital, but manages to obtain a higher value of production, a higher turnover and a profit higher gross operating costs, allowing for 
higher investments and higher gross value added compared to the Romanian "average" firm; (iv) at the same time, the higher profitability ratios for Romanian-owned companies conceal their significantly lower capacity to generate substantial investments and added value, while foreign-owned firms benefit, on average, from higher cash flows that are essential for business development; (v) between 2008 and 2014, the importance of foreign-owned companies has increased in the Romanian economy, which leads us to the conclusion that the overall performance of the Romanian economy has increased, given that the companies with foreign capital have better performances than those with Romanian capital.

Overall, our novel analysis in the Romanian academic literature supports the idea that the Romanian economy largely benefited from the activity of foreign-owned companies, whose contribution to growth has been substantial so far. Moreover, Romanian-owned companies should engage in the learning process from the former. At the same time, we stress on the need to build a welcoming business environment where the positive effects of foreign capital presence in Romania could manifest.

\section{References:}

Acarvaci, A., Ozturk, I. (2012): Foreign direct investment, export and economic growth: empirical evidence from new EU countries. Romanian Journal of Economic Forecasting 2: $52-$ 67.

Bartels, F., de Crombrugghe, S.A. (2009): FDI Policy Instruments: Advantages and Disadvantages. UNIDO Working Paper 01, Vienna.

Belaşcu, L., Popovici, O., Horobe , A. (2017): Foreign Direct Investments and Economic Growth in Central and Eastern Europe: A Panel-Based Analysis, In: Mărginean, S., Ogrean, C., Orăștean, R. (eds): Emerging Issues in the Global Economy. Springer Proceedings in Business and Economics. Cham: Springer International Publishing, 35-46.

Beugelsdijk, S., Smeets, R., Zwinkels, R.C.J. (2008): The impact of horizontal and vertical FDI on host's country economic growth. International Business Review 17: 452-472.

Buckley, P.J., Clegg, J., Wang, C. (2002): The Impact of Inward FDI on the Performance of Chinese Manufacturing Firms. Journal of International Business Studies 33(4). 637-655.

Damijan, J.P., Rojec, M, Ferjančič, M. (2008): Growing export performance of transition economies: EU market access versus supply capacity factors. LICOS- Centre for Institutions and Economic Performance Discussion Paper Series 202, Leuven.

Dunning, J.H. (1973): The determinants of International Production, Oxford Economic Papers 25(3): 289-336.

Dunning, J.H. (1988): The Eclectic Paradigm of International Production: A Restatement and Some Possible Extensions. Journal of International Business Studies 19(1): 1-31.

Gorg, H., Strobl, E. (2001): Multinational companies and productivity spillovers: A meta analysis. The Economic Journal 111(475): 723-739.

Hanousek, J., Kočenda, E., Maurel, M. (2011): Direct and indirect effects of FDI in emerging European markets: A survey and meta-analysis. Economic Systems 35(3), 301-322.

Hawawini, G., Subramanian, V., Verdin, P. (2003): Is performance driven by industry or firmspecific factors? A new look at the evidence. Strategic Management Journal 24(1): 1-16.

Horobe , A., Popovici, O., Belaşcu, L. (2018): Drivers of Competitiveness in European HighTech Industries, paper presented at "The Economies of the Balkan and the Eastern European Countries in the changing world (EBEEC)" Conference, May 11-13, 2018, Warsaw, Poland, http://ebeec.teikav.edu.gr/.

Iršová, Z., Havránek, T. (2013): Determinants of horizontal spillovers from FDI: Evidence from a large meta-analysis. World Development 42: 1-15. 
Kafouros, M.I., Buckley, P.J., Sharp, J.A. et al. (2008): The role of internationalization in explaining innovation performance. Technovation 28(1-2): 63-74.

Konings, J. (2001): The effects of foreign direct investment on domestic firms: evidence from firm level panel data in emerging economies. Economics of Transition 9(3): 619-633.

Kutan, A.M., Vuksic, G. (2007): Foreign Direct Investment and Export Performance: Empirical Evidence. Comparative Economic Studies 49(3): 430-445.

Meyer, K.E., Sinani, E. (2009): When and where does foreign direct investment generate positive spillovers? A meta-analysis. Journal of International Business Studies 40(7): 1075-1094.

Moura, R., Forte, R. (2010): The Effects of Foreign Direct Investment on the Host Country Economic Growth - Theory and Empirical Evidence, Universidade do Porto FEP Working Papers 390, Porto.

Porter, M.E. (1981): The Contributions of Industrial Organization to Strategic Management. The Academy of Management Review 6(4): 609-620.

Sgard, J. (2001): Direct foreign investments and productivity growth in Hungarian firms, 19921999. William Davidson Institute Working Paper 425, Ann Arbor.

Weche Gelubcke, J.P. (2011): The performance of foreign affiliates in German manufacturing: Evidence from a new database, University of Lüneburg Working Paper Series in Economics 216, Lüneburg. 